\title{
HAZOP Study and Determination of Safety Integrity Level Using Fault Tree Analysis on Fuel Gas Superheat Burner of Ammonia Unit in Petrochemical Plant, East Java
}

\author{
Ronny Dwi Noriyati ${ }^{1, *},{ }^{2}$ Amarendra B.Prakoso. ${ }^{2}$, Ali Musyafa ${ }^{3}$ and Adi Soeprijanto ${ }^{4}$ \\ ${ }^{1}$ Department of Electrical Engineering, Faculty of Industrial Technology \\ Kampus ITS, Jl.A.R. Hakim, Surabaya - Indonesia, 60111 \\ ${ }^{2}$ Department of Engineering Physics, Faculty of Industrial Technology \\ Kampus ITS, Jl.A.R. Hakim, Surabaya - Indonesia, 60111 \\ ${ }^{3}$ Department of Engineering Physics, Faculty of Industrial Technology \\ Kampus ITS, Jl.A.R. Hakim, Surabaya - Indonesia, 60111 \\ ${ }^{4}$ Professor Department of Electrical Engineering, Faculty of Industrial Technology \\ Kampus ITS, Jl.A.R. Hakim, Surabaya - Indonesia, 60111 \\ ${ }^{*}$ Corresponding author's emaill: onny [AT] ep.its.ac.id
}

\begin{abstract}
Safety is an essential requirement in the course of production in the industry. Security in the factory needs to be considered, especially against malicious nodes such as burner. In this research analysis to determine opportunities hazard that could happen to superheat burner. The magnitude of the risk of harm must be balanced with the security system (SIS). So the system superheat burner analyzed by the method HAZOP and SIL safety level calculated through the method of FTA. Based on research conducted in this thesis, superheat burner has a high danger risk (high risk) component TT-1005 and PT-1018. The level of security superheat burner classified SIL 1 with PFD 4.38x10-2, so do redesign the SIS to achieve SIL 2. PFD system of 0.0099 is achieved by adding 2 ESDV on line check fuel gas and purges gas and increase the pressure switch on each function pressure switch. (PSHH, PSL, PSLL).
\end{abstract}

Keywords- burner, safety, SIS, FTA, SIL.

\section{INTRODUCTION}

The main products of the fertilizer industry Petrochemical East-java is nitrogen and phosphate fertilizers. Fertilizer industry requires major raw materials; ammonia, sulfuric acid and phosphoric acid. Urea Fertilizer $\left(\mathrm{NH}_{2} \mathrm{CONH}_{2}\right)$ is one of the fertilizers that use Ammonia $\left(\mathrm{NH}_{3}\right)$ as the raw material, with a mixture of Carbondioxide $\left(\mathrm{CO}_{2}\right)$, in which both of them are obtained as a result of natural gas synthesis. The process of urea fertilizer making needs a catalyst, a compound that has function to fasten the chemical reaction. The catalyst used in ammonia is mostly shaped in the form of solid, except DEA (Diethanol Amione) which is in the form of liquid. If urea fertilizer production result accidentally enters the water, it will give the long-term impact which is eutrophication. Some of the effects are the occurrence of smelly odor, reduction in environment quality, and also give a health problem to human. To prevent those things, some methods of waste processing are done by equalization, neutralization, precipitation, and biological processing [1]. While one of the important process steps in the manufacture of ammonia is steam production that is used to support the production of the factory. The function of steam as a heat source as a fluid heat exchange is as fluid for pneumatic control valve. Supply needs of steam conducted through the steam conditioning process that is integrated in the steam system. Phase manufacture of high quality steam include: steam supply, dieresis, steam generating, steam separation and steam superheating.

The process of steam generation needs some equipment, such as deaerator, and Heat Exchanger, and Burner steam high pressure. Burner superheat steam process works at a pressure of $120 \mathrm{~kg} / \mathrm{cm}^{2}$ and a temperature in the range of $300-$ $500^{\circ} \mathrm{C}$. Plant recorded throughout the year 2014-2015 has been a trip seven times in ammonia plant. Twice partly as a result of superheat burner failed to maintain stability control complement system [1]. The trip to the factory surely disrupts production activities and corporate losses. Superheat steam system is a system that is very critical [2], because 
the operational temperature and relatively high working pressure. So the greater the chances of the occurrence of hazards and risks serious consequences. Proved that the instrument mounted on superheated have a higher risk of harm than the other nodes. Therefore Instruments installed outside superheat also have levels of extreme danger risk [3]. Then the security of the steam system must be considered because they affect the quality of the products of steam. So that the risk can be reduced to a minimum through maintenance, calibration and business risks decreased.

When the system state is out of control, it would require an analysis of the SIS security system as a whole, with the identification and prevention fail state. [4]. A burner has the potential hazards and risks are great at a petrochemical industry for the plant are oil and gas. As the components that are vulnerable to fire and exploded, enter the fuel consumption is hazardous high into the system so that the necessary existence of a safety system to prevent an explosion, an accident, even the loss of a human life [5]. First have to identify hazards in the system using Hazard analysis and Operability Study (HAZOP). Through HAZOP can do testing on every part of the process to determine the possibility of deviation from the state of design. Understanding the causes and consequences from hazards. Of the existing problems, the researchers conducted "Hazard and Operability Study (HAZOP) and safety instrumented system (SIS) by the method of Fault Tree Analysis. So the SIS on Fuel Gas Burner superheat can improve system security and reduces the risk of imminent danger.

\section{MATERIAL AND METHOD}

\subsection{Primary Reformer Steam (Superheat Burner)}

He production process is facilitated ammonia steam with high temperature and high pressure. Steam is used here to support the ammonia plant utilities, among others as a working fluid turbine, compressor, and a heat source as the media heat exchanger, used by the instrument to power pneumatic system. Steam produced by equipment called steam system as shown in Figure 2.1. In this system is the integration of several important nodes, among others; de-eretaor, steam drums, heat exchangers, and superheat primary reformer. In research carried out analysis on the primary superheat steam reformer burner. Superheat steam burner generates heat that burned advanced directly through the media coil tube using fuel gas methane $(\mathrm{CH} 4)$. So that the steam generated has a pressure of $+120 \mathrm{~kg} / \mathrm{cm} 2$ and temperature $+\mathrm{C}^{\circ} 520$. Figure 1 .

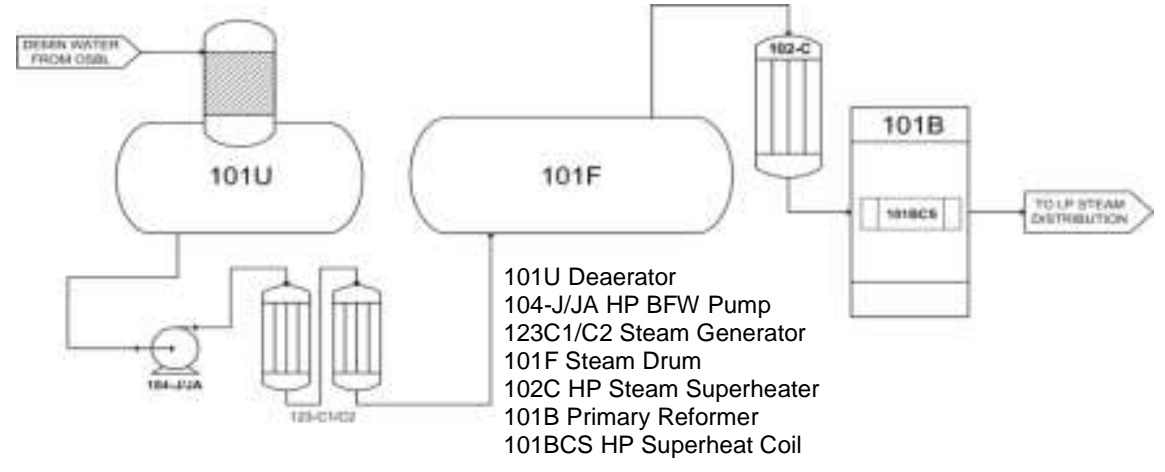

Figure 1. Process Flow Diagram of Steam System

Steam produced by the system are distributed and utilized into three levels based on the pressure of steam, among others:

a. High Pressure (HP) Steam $+120 \mathrm{~kg} / \mathrm{cm} 2$

HP steam is used to drive turbines and 103JT 101JT. The heat source heater 173C and 172C1

b. Medium Pressure (MP) Steam $+40 \mathrm{~kg} / \mathrm{cm} 2$

MP Steam obtained from the extraction 101JT, 103JT as well as the supply of WHB used for the manufacture of ammonia, turbine propulsion, and re-boiler at $140 \mathrm{C}$

c. Low Pressure (LP) Steam $+4 \mathrm{~kg} / \mathrm{cm} 2$

LP Steam is obtained from steam turbine discharge, the flash of blow down drum $156 \mathrm{~F}, 157 \mathrm{~F}$ is used to drive turbines

JT, and steam service. [1]

\subsection{Hazard and Operability (HAZOP) Study}

Hazard and Operability Study HAZOP or referred to is the method used to analyze the hazards in a system. The system uses qualitative techniques to identify potential hazards by using your word. HAZOP is used to describe any part of the process to be known deviations from the design which has been made and assess the causes and consequences that pose a danger to the system. From the schematic next system built guidewords appropriate system. The HAZOP analysis contains several important elements: 
- The analysis process is a creative process that systematically use some guideword to identify deviations into the potential dangers of the design process and use this aberration as "triggering device" as a guide in the analysis of identification potential hazards, impact or the consequences that may occur.

- HAZOP analysis performed by personnel with basic knowledge about the process and analyzed using a logical mindset in every definition of the potential hazards.

- Any problems that finished identified, documented in an assessment table.

In HAZOP analysis there are some parameters that are standard in determining the value and level of danger in every component. Parameters used include; likelihood, consequence, and risk matrix. Likelihood is the chance of risk of harm to the components. Parameters used refers to the likelihood that the standard criteria likelihood "Production Departmen I PT. PKG "shown Table 1.

Table 1. Criteria Likelihood PT. Petrokimia Gresik [1]

\begin{tabular}{c|l|l}
\hline No & \multicolumn{1}{|c}{ Ranking } & \multicolumn{1}{c}{ Discription } \\
\hline $\mathbf{1}$ & Brand New Excellent & Risk frequency of occurrence is less than four times in 10 years \\
\hline $\mathbf{2}$ & Very Good / Good Serviceable & Risk of 4-6 times in 10 years \\
\hline $\mathbf{3}$ & Acceptable & Risks occur between 6-8 times in 10 years \\
\hline $\mathbf{4}$ & Below Standard / Poor & Risks occur between 8-20 times in 10 years \\
\hline $\mathbf{5}$ & Bad / Unacceptable & Risk occurs 10 times in 10 years \\
\hline
\end{tabular}

Parameter consequence describes the level of danger of the impact caused by the risk of deviations from the desired state or operating out of control. Reviews carried out based on the impact and the effect on factory activity and production. Standards to determine the consequence refers to the standard criteria factory consequence I PT. PKG shown by Table 2 .

Table 2. Criteria Consequence PT. Petrokimia Gresik [1]

\begin{tabular}{c|l|l}
\hline No & \multicolumn{1}{|c|}{ Ranking } & \multicolumn{1}{c}{ Discription } \\
\hline 1 & Insignificant & $\begin{array}{l}\text { Sources of risk (elements / components / objects in the activity) are not impacted at all, } \\
\text { consequently no significant effect on the continuity of activities, so that activities } \\
\text { remain implemented }\end{array}$ \\
\hline 2 & Minor & $\begin{array}{l}\text { Sources of risk (elements / components / objects in the activity) have little impact, } \\
\text { resulting in little impact on the continuity of activities, so that activities still happen }\end{array}$ \\
\hline 3 & Moderate & $\begin{array}{l}\text { Sources of risk (elements / components / objects in the activity) of a moderate impact, } \\
\text { the result was the continuation of activities, so that activities still happen }\end{array}$ \\
\hline 5 & Majastrophic & $\begin{array}{l}\text { Sources of risk (elements / components / objects in the activity) have a major impact, } \\
\text { consequently significantly to the continuity of the activity, but the activity can still be } \\
\text { implemented, although not optimal }\end{array}$ \\
\hline & $\begin{array}{l}\text { Sources of risk (elements / components / objects in the activity) have an enormous } \\
\text { impact, the consequences are very significant to the continuity of activities, so that } \\
\text { activities cannot be implemented }\end{array}$ \\
\hline
\end{tabular}

Parameter risk ranking is the result of multiplying the likelihood and consequence hazard criteria will be displayed in the matrix, where Risk = Consequence $(\mathrm{C}) \mathrm{x}$ Likelihood $(\mathrm{L})$, which is shown by Table.3.

Table 3. Risk Matrix ranking PT. Petrokimia Gresik [1]

\begin{tabular}{|l|c|c|c|c|c|}
\hline \multirow{2}{*}{ Likelihood } & \multicolumn{5}{|c|}{ Consequence } \\
\cline { 2 - 6 } & 1, Insignificant & 2, Minor & 3 , Moderate & 4. Major & 5, Catastrophic \\
\hline 1.Brand New Ecxellent & L1 & L2 & L3 & L4 & M5 \\
\hline 2.Good & L2 & L4 & M6 & M8 & M10 \\
\hline 3.Acceptable & L3 & M6 & M9 & M12 & H15 \\
\hline 4.Poor & L4 & M8 & M12 & H16 & H20 \\
\hline 5.Unacceptable & M5 & H10 & H15 & H20 & H25 \\
\hline
\end{tabular}

Where:

$\mathrm{L}=$ low risk

$\mathrm{M}=$ moderate risk

$\mathrm{H}=$ high risk 


\subsection{Safety Integrity Level (SIL)}

SIL is the security level of safety instrumented system (SIS). SIL is defined as SIL 1, 2, 3, and high 4.Semakin SIL levels, the better the security of SIS. SIL major parameters measured by PFD (Probability Failure on Demand) for categorized SIL 1 if the value is greater PFD equal to 0:01 and smaller than 0.1. For categories other SIL levels can be seen in Table 4. SIS better performance is achieved with the availability of higher security. SIS Performance is enhanced with the addition of redundancy, more frequent testing, and the use of error detection. Some understanding of how the three levels of SIL implemented is critical to the security of the process in determining the SIL. With an understanding of the importance of the safety aspects of the SIS, including what is needed to achieve different SIL. [9]

Table 4. Safety Integrity Level for SIF [9]

\begin{tabular}{c|c|c}
\hline SIL categories & $\boldsymbol{P F D ~ S I F}$ & $\boldsymbol{R R F}=(\mathbf{I} / \boldsymbol{P F D})$ \\
\hline NR- not requirement & $1 \leq \mathrm{PFD}$ & $\mathrm{RRF} \leq 1$ \\
\hline SIL 1 & $10^{-2} \leq \mathrm{PFD}<10^{-1}$ & $10^{1}<\mathrm{RRF} \leq 10^{2}$ \\
\hline SIL 2 & $10^{-3} \leq \mathrm{PFD}<10^{-2}$ & $10^{2}<\mathrm{RRF} \leq 10^{3}$ \\
\hline SIL 3 & $10^{-4} \leq \mathrm{PFD}<10^{-3}$ & $10^{3}<\mathrm{RRF} \leq 10^{4}$ \\
\hline SIL 4 & $10^{-5} \leq \mathrm{PFD}<10^{-4}$ & $10^{4}<\mathrm{RRF} \leq 10^{5}$
\end{tabular}

Source: ISA TR 84.00.02-2002

Safety integrity level (SIL) is determined by calculating the probability of a failure will occur using the equation.

$$
\lambda=1 / \text { MTTF }
$$

Where: $\lambda=$ failure rate (laju kegagalan); MTTF $=$ Mean Time To Failure

Likelihood obtained from the comparison of the operating time of the components of the average number of component failures to the time following failure.

$$
\text { Likelihood }=\frac{\text { Operating time }}{\text { MTTF }}
$$

The determination of the SIL is very important in the manufacturing lifecycle stages SIL. Met ode in SIL calculations using quantitative methods derived from the calculation of the repair data as well as instrument implemented. After components that define the configuration of equipment arranged in Moon channel. If the equipment connected in series, the series will be calculated failure rate. For configuration Moon channel the formula used to calculate the PFD is [10]:

$$
\begin{aligned}
& P_{1001}=\lambda^{D U} x \frac{T I}{2} \\
& \text { PFD }_{1002}=\frac{\left\lfloor\left(\lambda^{D U}\right)^{2} x T I^{2}\right\rfloor}{3} \\
& \text { PFD }_{1003}=\frac{\left\lfloor\left(\lambda^{D U}\right)^{\mathrm{s}} x T I^{\mathrm{s}}\right\rfloor}{4} \\
& \text { PFD }_{2002}=\lambda^{D U} \times T I \\
& \text { PFD }_{2003}=\left(\lambda^{D U}\right)^{2} \times T I^{2} \\
& \text { PFD }_{2004}=\left(\lambda^{D U}\right)^{3} \times T I^{3}
\end{aligned}
$$

Where:

PFD $_{\text {MooN }}=$ Probability Failure on Demand Average

$\lambda^{D U}$ (Lambda) = failure rat

TI = Interval time / test function (hour)

$$
P F D_{s y s}=P F D_{s}+P F D_{I}+P F D_{f s}
$$

Where:

$P F D_{\text {sys }}$ : PFD rate from safety function-safety related system 
PFD $D_{s} \quad:$ PFD from sensor subsystem

$P F D_{l} \quad:$ PDD from DCS

PFD $D_{f e}:$ PFD from final element subsystem

\subsection{Flowchar of Research}

This research stage following the steps as shown in Figure 2. In more detail includes the following activities:

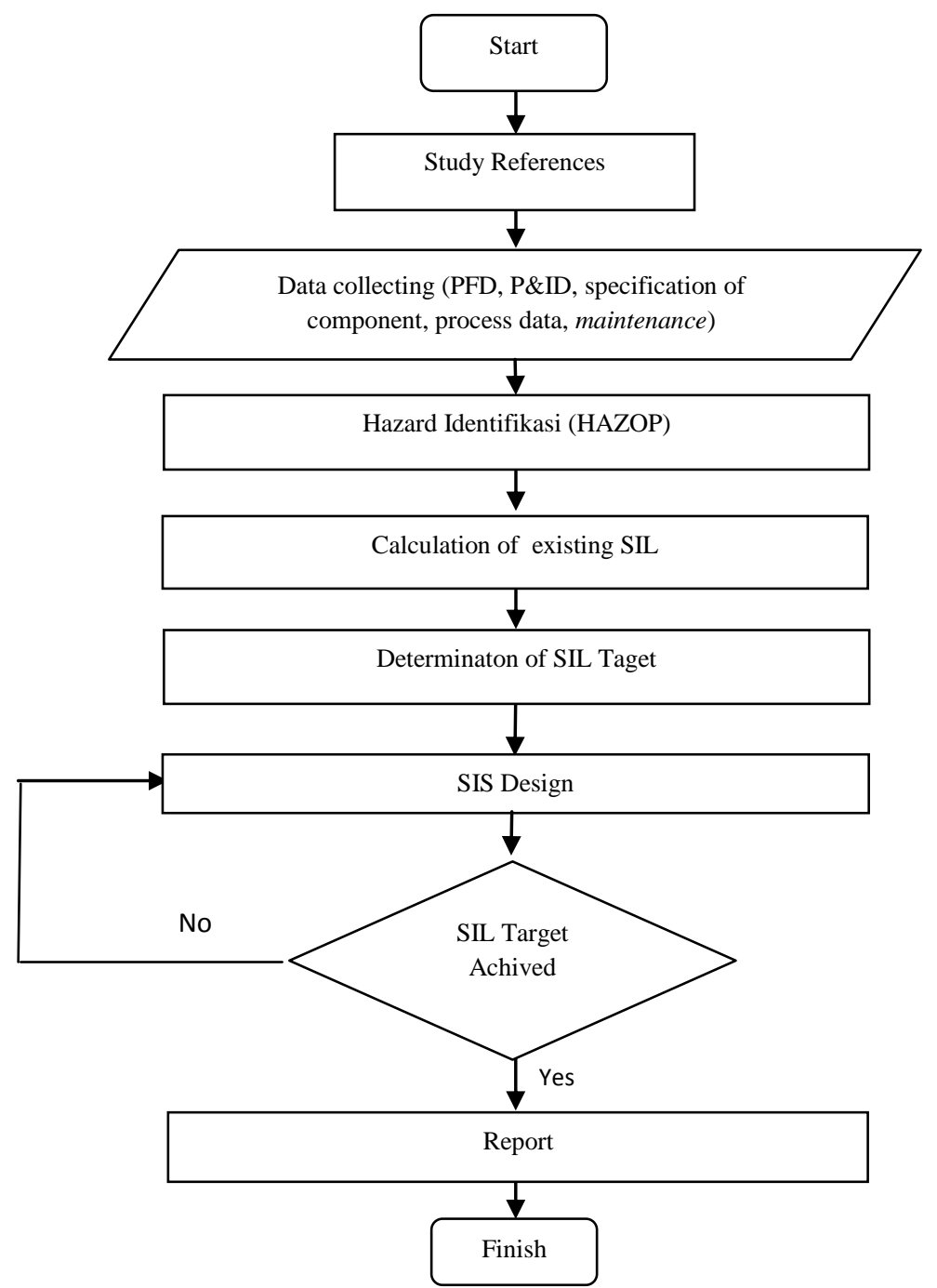

Figure 2. Flowchart of the research

Step-step research activities include;

a. Literature by searching literature journals, books and other publications related to the theme research.

b. The data collection is done by taking pictures of the P \& ID, PFD, component specifications, the data maintenance of nodes superheat burner (101BBS), primary reformer (101B) server. Data retrieval the recording process for one month.

c. Hazard identification was conducted using HAZOP (Hazard Operability Study). Covering risks, opportunities danger, deviation superheat processes that occur on the burner, so that the risk value can be determined based on the level of frequency and consequences occur.

d. SIL calculation obtained by the existing FTA method by calculating each PFD components that represent each event. SIL value superheat burner system is calculated from the total PFD SIS components that make up the node superheat. So that the security level of the system can be known.

e. Determining Target SIL as a follow-up analysis of the risks and SIL calculation of existing plant to produce recommendations to minimize the danger to the value of SIL consensus in a way component members add safety and 
security activities to reduce the risk. Level SIL upgraded one notch higher.

f. The design of the SIS as an effort to increase security by adding and changing the configuration of the security system.

\section{ANALYSIS AND DISCUSSION}

To produce steam carried out in several stages, carried on with de-erator dieresis $101 \mathrm{U}$, continued preheat the heat exchanger $123 \mathrm{C} 1 / \mathrm{C} 2$, the separation between the vapor and liquid phase in the steam drum 101F. Dry steam is produced with advanced high temperature heating with heating coil 101B primary reformer. Activity form directly through the combustion burner superheat. Product specification steam has a temperature $=520^{\circ} \mathrm{C}$ and pressure $=120 \mathrm{~kg}$ $/ \mathrm{cm} 2$. Steam products further distributed to the ammonia unit. Vapor product consists of three types; high pressure (HP), medium pressure (MP), and low pressure (LP). Each product is used according to need. So that the primary role of reformer very vital because directly related to combustion and processes with process variables are relatively high, further analysis is focused on the primary node reformer in the form of coil superheat and Uren superheat.

Potential hazards assessed based on the log sheet and the data obtained from the DCS data history, data is sampled with acquisition pattern every four hours of operation at the primary reformer transmitter 101B. Potential hazards of known trends based on average data deviation operations. Obtained through the guide word expressed by the deviation. Temperature transmitter 1005 (TT1005) loop temperature control to maintain the temperature of steam output. P \& ID superheat Burner is shown in Figure 3.

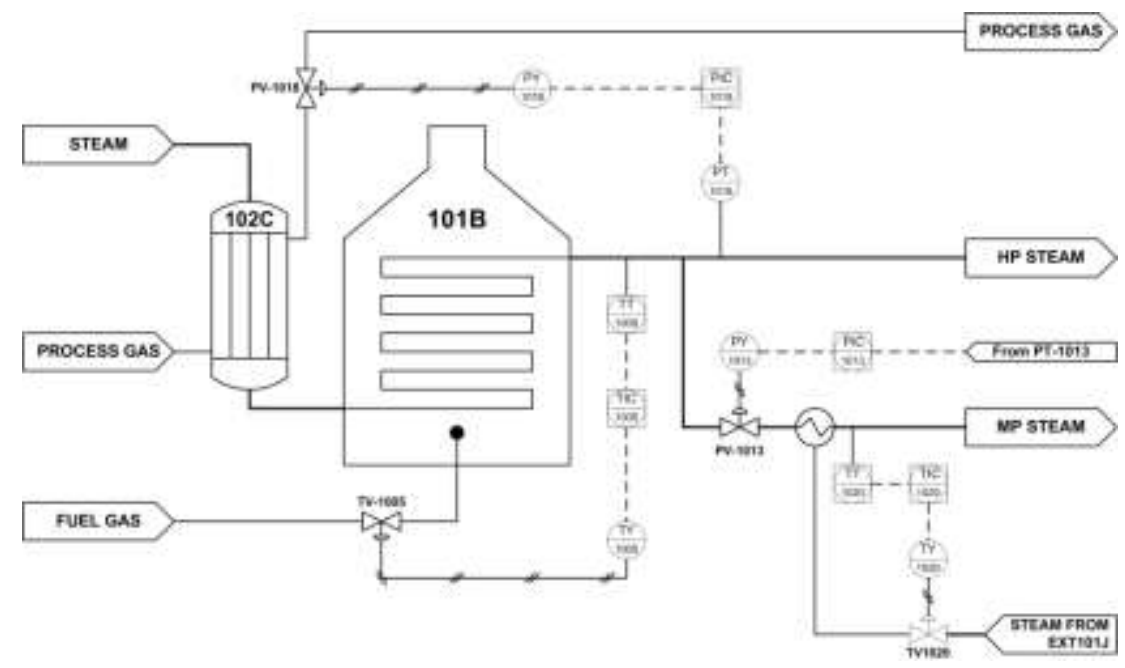

Figure 3. P\&ID Superheat Burner

From the historical data can be further built TT1005 control chart graph. Indicated that the process has deviated to the value are above and below the mean value. Furthermore, the determination guideword and high and low deviation is shown in Figure 4.

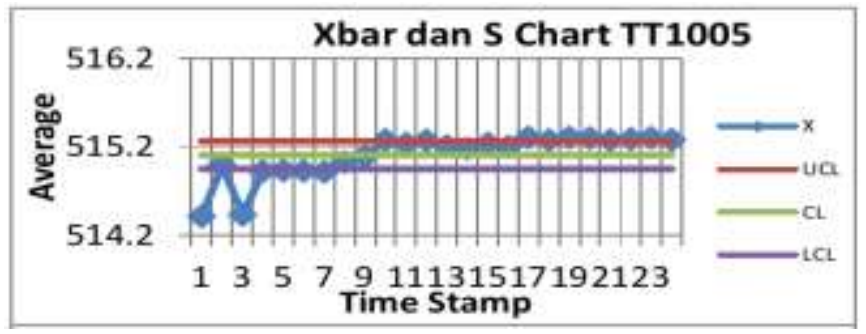




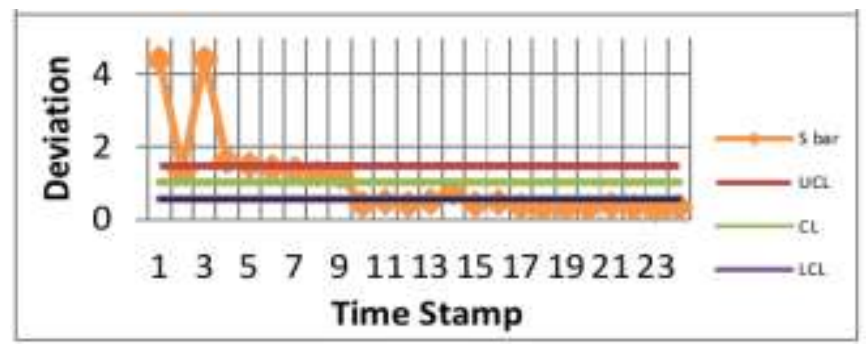

Figure.4. Control Chart of Bar-S TT-1005

Table 5. Guideword of node superheat burner

\begin{tabular}{|c|c|c|c|c|}
\hline No. & Coponent & Description & Guideword & Deviation \\
\hline \multirow{2}{*}{1} & \multirow{2}{*}{ TT1105 } & \multirow{2}{*}{ Temperature Transmitter } & High & High Temperature \\
\hline & & & Low & Low Temperature \\
\hline \multirow{2}{*}{2} & \multirow{2}{*}{ PT1018 } & \multirow{2}{*}{ Pressure Transmitter } & High & High Pressure \\
\hline & & & Low & Low Pressure \\
\hline \multirow{2}{*}{3} & \multirow{2}{*}{ TT1020 } & \multirow{2}{*}{ Pressure Transmitter } & High & High Pressure \\
\hline & & & Low & Low Pressure \\
\hline \multirow{2}{*}{4} & \multirow{2}{*}{ PT1013 } & \multirow{2}{*}{ Temperature Transmitter } & High & High Temperature \\
\hline & & & Low & Low Temperature \\
\hline \multirow{2}{*}{5} & \multirow{2}{*}{ FI1031 } & \multirow{2}{*}{ Flow Transmitter } & More & More Flow \\
\hline & & & Less & Less Flow \\
\hline \multirow{2}{*}{6} & \multirow{2}{*}{ TI1336 } & \multirow{2}{*}{ Temperature Transmitter } & High & High Temperature \\
\hline & & & Low & Low Temperature \\
\hline 7 & TV-1005 & Control Valve & Open & Fail to open \\
\hline 8 & PV-1018 & Control Valve & Close & Fail to close \\
\hline 9 & PV-1013 & Control Valve & Open & Fail to open \\
\hline 10 & TV-1020 & Control Valve & Open & Fail to open \\
\hline
\end{tabular}

Levels of risk are expressed in a matrix. To provide value parameter refers to the likelihood and consequence of each standard. Likelihood value is determined using data maintenance, instrument calibration obtained from Dept. Maintenance. As for the components for which data are available traceability data contained in the manual book OREDA (Offshore Reliability Data) 2002.

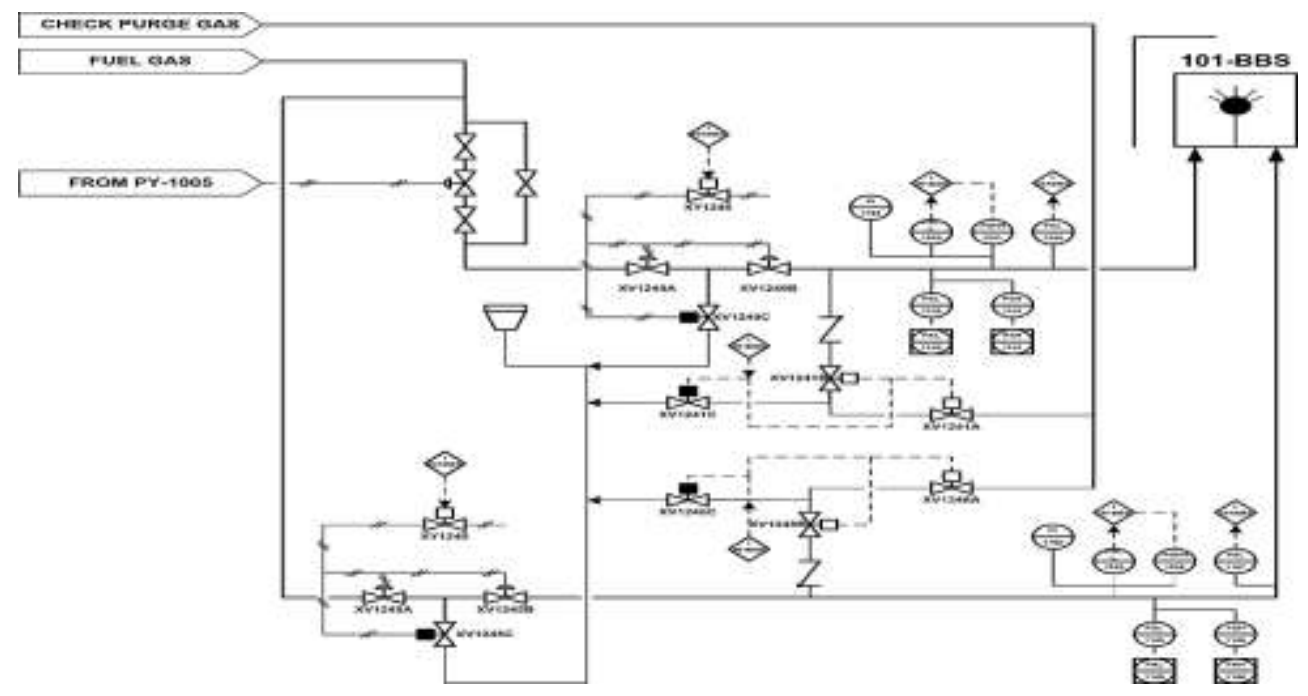

Figure 5. P \& ID Superheat Burner 
Likelihood value is calculated by dividing time operating instrument against the mean time to failure (MTTF). So as to superheat node burner at risk for each component Consequence is determined to seek severity (severity) impacts that occur the risk of deviations from the desired state. Based on the standard process data and operational implementation (SOP) ammonia plant can then be determined according to the severity level of consequences category table 6 .

Table 6. Likelihood, Consequence and Risk Ranking in Superheat burner

\begin{tabular}{|c|c|c|c|c|}
\hline \multirow{2}{*}{ No. } & \multirow{2}{*}{ Component } & $\boldsymbol{L}$ & $\boldsymbol{C}$ & $\boldsymbol{R} \boldsymbol{R}$ \\
\hline \multirow{2}{*}{2} & \multirow{2}{*}{$\mathrm{TT} 1005$} & 4 & 5 & $\mathrm{H} 20$ \\
\cline { 3 - 5 } & \multirow{2}{*}{$\mathrm{PT} 1018$} & 4 & 5 & $\mathrm{H} 20$ \\
\hline \multirow{2}{*}{3} & \multirow{2}{*}{$\mathrm{PT} 1013$} & 4 & 5 & $\mathrm{H} 20$ \\
\cline { 3 - 5 } & & 4 & 5 & $\mathrm{H} 20$ \\
\hline \multirow{2}{*}{4} & \multirow{2}{*}{$\mathrm{PT} 1020$} & 3 & 2 & $\mathrm{M} 6$ \\
\hline \multirow{2}{*}{5} & \multirow{2}{*}{$\mathrm{FI} 1031$} & 2 & 2 & $\mathrm{M} 6$ \\
\hline \multirow{2}{*}{6} & \multirow{2}{*}{$\mathrm{TI} 1031$} & 2 & 3 & $\mathrm{M} 6$ \\
\cline { 3 - 5 } & & 2 & 3 & $\mathrm{M} 6$ \\
\hline 7 & $\mathrm{TV}-1005$ & 1 & 2 & $\mathrm{M} 6$ \\
\hline 8 & $\mathrm{PV}-1018$ & 1 & 2 & $\mathrm{M} 6$ \\
\hline 9 & $\mathrm{PV}-1013$ & 1 & 3 & $\mathrm{~L} 2$ \\
\hline 10 & $\mathrm{TV}-1020$ & 1 & 2 & $\mathrm{~L} 2$ \\
\hline & & & 2 & $\mathrm{~L} 2$ \\
\hline
\end{tabular}

Security systems burner superheat implement security layer Safety instrumented system (SIS). SIS consists of a sensing element in the form of switches, controllers such as PLCs, the final element in the form of valve / solenoid valve. The security system installed on the components that have a high chance of danger. Fuel burner using methane gas (CH4) is supplied from the fuel gas. Direct burning combustion manifold which has two gases feed pipe line for supplying the gas burner and each line has a safety system SIS. SIL calculation by the method of the FTA, the SIS system superheat burner using PFD value derived from the data maintenance. Because there are limited data maintenance, then the pressure switch components, PLC and solenoid valve XY1240 XY1245 using values based OREDA 2002. The failure rate of the components of SIS PFD superheated burner shown in table 7.

Table 7. Values \& PFD component failure rate superheat Burner.

\begin{tabular}{c|c|r|r|r}
\hline NO & Instrumen & Failure Rate & PFD & SIL \\
\hline \multirow{4}{*}{1} & Pressure Switch & $2.00 \times 10^{-6}$ & $8.76 \times 10^{-3}$ & 2 \\
& - PSHH & $2.00 \times 10^{-6}$ & $8.76 \times 10^{-3}$ & 2 \\
& - PSLL & $2.00 \times 10^{-6}$ & $8.76 \times 10^{-3}$ & 2 \\
& - PSL & $2.00 \times 10^{-6}$ & $8.76 \times 10^{-3}$ & 2 \\
& - PSHH & $2.00 \times 10^{-6}$ & $8.76 \times 10^{-3}$ & 2 \\
& - PSLL & $2.00 \times 10^{-6}$ & $8.76 \times 10^{-3}$ & 2 \\
\hline 2 & - PSL & $1.43 \times 10^{-4}$ & 3 \\
\hline \multirow{4}{*}{3} & Final Element & & & \\
& - XY1240 Safety Manager & $2.102 \times 10^{-3}$ & 2 \\
& - XV1240 & $2.211 \times 10^{-5}$ & $2.102 \times 10^{-3}$ & 1 \\
& - XY1245 & $4.800 \times 10^{-7}$ & $1.195 \times 10^{-2}$ & 2 \\
& - XV1245 XV1241 & $2.162 \times 10^{-5}$ & $1.196 \times 10^{-2}$ & 1 \\
& - XV1246 & $2.163 \times 10^{-5}$ & $1.196 \times 10^{-2}$ & 1 \\
\hline
\end{tabular}

Through analysis of the FTA, the calculation of the value of the SIL superheat burner searched through the stages shown in Figure 6. 


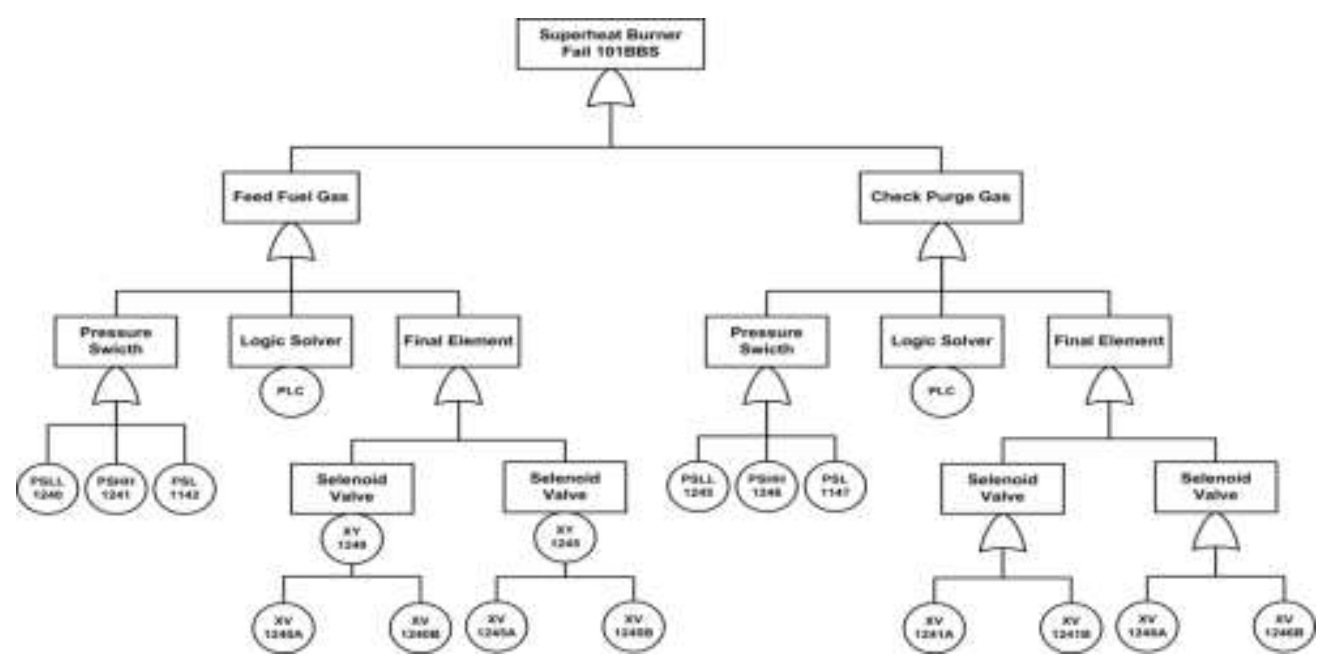

Figure 6. FTA Superheat Burner.

Through analysis of the FTA SIL superheat value calculation burner is calculated as follows.

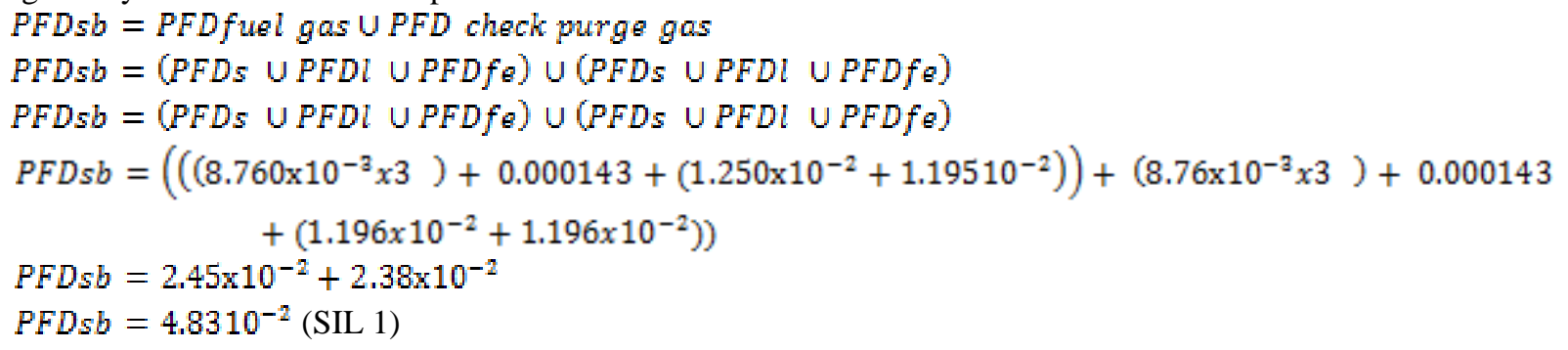

An increase in SIL, once obtained is calculated PFD of SIS system superheat SIL burner system. Moon SIS channel configuration obtained by sensing combination element (pressure switch) and the final element (valve) and the value PFD tabulated tables 4.4 and 4.5 as well as SIL combination of SIS in Table 8.

Table 8. Value PDF and SIL Pressure Switch

\begin{tabular}{c|c|c}
\hline \multirow{2}{*}{ Configures } & PFD Pressure Switch & SIL \\
\cline { 2 - 3 } & $\lambda 0.000002$ & 2 \\
\hline 1001 & $8.760 \times 10^{-3}$ & 4 \\
\hline 1002 & $7.674 \times 10^{-5}$ & 4 \\
\hline 1003 & $6.722 \times 10^{-7}$ & \\
\hline
\end{tabular}

PFD calculation of the pressure switch using a data failure rate of Oreda book in 2002 for maintenance of data showing the absence of failure for 20 years operating ammonia plant. So for now on SIS superheat burner consists of three pressure switch (PSHH, PSLL, PSL) to the fuel feed line and a gas line purge gas check. Overall ESDV value of existing SIL 1. So as to achieve the necessary modifications to the configuration ESDV from Table 4.6 written SIL 2 can be achieved with a combination of configuration ESDV 6 and switch after. PFD value and the SIL of a variety of configurations do a combination of the sensing element and final element in table 9.

Table 9. Value PFD and SIL Final Element ESDV

\begin{tabular}{|c|c|c|c|c|c|c|}
\hline \multirow{3}{*}{$\begin{array}{l}\text { Konfi } \\
\text { guration }\end{array}$} & \multicolumn{6}{|c|}{ PFD Final element } \\
\hline & XV1240 & XV1245 & XV1241 & XV1246 & XY1240 & XY1245 \\
\hline & $\lambda \quad 2.21 \times 10^{-5}$ & $\lambda \quad 2.16 \times 10^{-5}$ & $2.16 \times 10^{-5}$ & $2.16 \times 10^{-5}$ & $\lambda 4.80 \times 10^{-7}$ & $\lambda 4.80 \times 10^{-7}$ \\
\hline 1001 & $9.684 \times 10^{-2}$ & $9.468 \times 10^{-2}$ & $9.474 \times 10^{-2}$ & $9.474 \times 10^{-2}$ & $2.102 \times 10^{-3}$ & $2.102 \times 10^{-3}$ \\
\hline 1002 & $1.250 \times 10^{-2}$ & $1.195 \times 10^{-2}$ & $1.197 \times 10^{-2}$ & $1.197 \times 10^{-2}$ & $5.893 \times 10^{-6}$ & $5.893 \times 10^{-6}$ \\
\hline 1003 & $1.816 \times 10^{-3}$ & $1.698 \times 10^{-3}$ & $1.701 \times 10^{-3}$ & $1.701 \times 10^{-3}$ & $1.859 \times 10^{-8}$ & $1.859 \times 10^{-8}$ \\
\hline 2002 & $1.937 \times 10^{-1}$ & $1.894 \times 10^{-1}$ & $1.895 \times 10^{-1}$ & $1.895 \times 10^{-1}$ & $4.205 \times 10^{-3}$ & $4.205 \times 10^{-3}$ \\
\hline 2003 & $3.751 \times 10^{-2}$ & $3.586 \times 10^{-2}$ & $3.590 \times 10^{-2}$ & $3.590 \times 10^{-2}$ & $1.768 \times 10^{-5}$ & $1.768 \times 10^{-5}$ \\
\hline 2004 & $7.266 \times 10^{-3}$ & $6.790 \times 10^{-3}$ & $6.803 \times 10^{-3}$ & $6.803 \times 10^{-3}$ & $7.434 \times 10^{-8}$ & $7.434 \times 10^{-8}$ \\
\hline
\end{tabular}


Tabel 10. The resulting value is a combination SIL SIS Fuel Gas Line

\begin{tabular}{|c|c|c|c|c|c|c|c|c|}
\hline \multirow[t]{3}{*}{ NO. } & \multirow{2}{*}{\multicolumn{2}{|c|}{ Sensing Element }} & \multirow{3}{*}{$\begin{array}{c}\text { SIL Logic } \\
\text { Solver PLC }\end{array}$} & \multicolumn{4}{|c|}{ Final Element } & \multirow[t]{3}{*}{ SIL SIS } \\
\hline & & & & \multicolumn{2}{|c|}{ ESDV } & \multicolumn{2}{|c|}{ Solenoid Valve } & \\
\hline & Configures & SIL & & Configures & SIL & Configures & SIL & \\
\hline 1 & 1001 & 2 & 3 & 1003 & 2 & 1001 & 2 & 2 \\
\hline 2 & 1001 & 2 & 3 & 2002 & 0 & 1002 & 4 & 0 \\
\hline 3 & 1001 & 2 & 3 & 2003 & 1 & 1003 & 4 & 1 \\
\hline 4 & 1001 & 2 & 3 & 2004 & 2 & 2002 & 2 & 2 \\
\hline 5 & 1002 & 4 & 3 & 1003 & 2 & 1001 & 2 & 2 \\
\hline 6 & 1002 & 4 & 3 & 2002 & 0 & 1002 & 4 & 0 \\
\hline 7 & 1002 & 4 & 3 & 2003 & 1 & 1003 & 4 & 1 \\
\hline 8 & 1002 & 4 & 3 & 2004 & 2 & 2002 & 2 & 2 \\
\hline 9 & 1003 & 4 & 3 & 1003 & 2 & 1001 & 2 & 2 \\
\hline 10 & 1003 & 4 & 3 & 2002 & 0 & 1002 & 4 & 0 \\
\hline 11 & 1003 & 4 & 3 & 2003 & 1 & 1003 & 4 & 1 \\
\hline 12 & 1003 & 4 & 3 & 2004 & 2 & 2002 & 2 & 2 \\
\hline
\end{tabular}

An increase in SIL base on the voting system targets Moon SIL 2 can be achieved through the six combinations; switch between sensing element and final element (ESDV) Table 4.6. Calculation combination table SIS-2 has a combination of numbers $1,4,5,8,9$. From the comparison calculation of some combination of SIS system, then obtained the system reaches SIL 2 combination number 5 with PFD 0.010. The combination of the number 5 is composed of sensing element 10o2, 1003 ESDV (XV1241-1246) and 10o1 (XY1240 and 1245) and requires additional instrument 6 and the second pressure switch control valve and the second solenoid valve. When compared to the combination of $\mathrm{X}$ number also achieves SIL 2. Implementation of an increase in SIL with the addition ESDV actuator configured 1003 and 1002 pressure switch sensing element generates a configuration that can be applied to SIS superheated burner, shown in Figure 7.

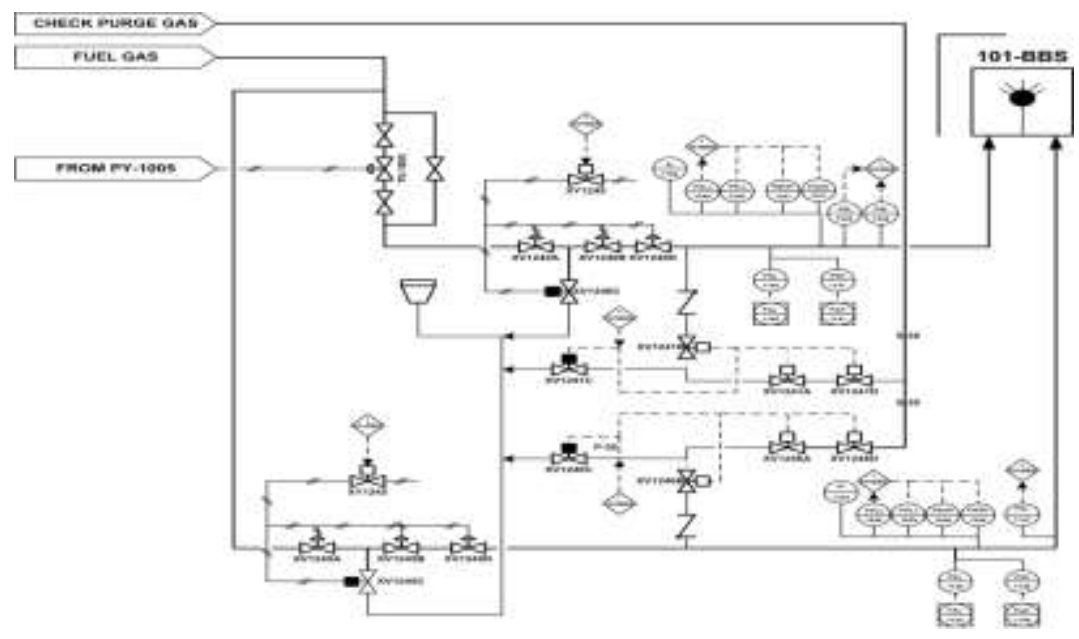

Figure 7. P \& ID SIS Superheat Burner

Through a combination of SIS number 5 configuration using FTA method obtained SIL value calculation of superheat following burner.

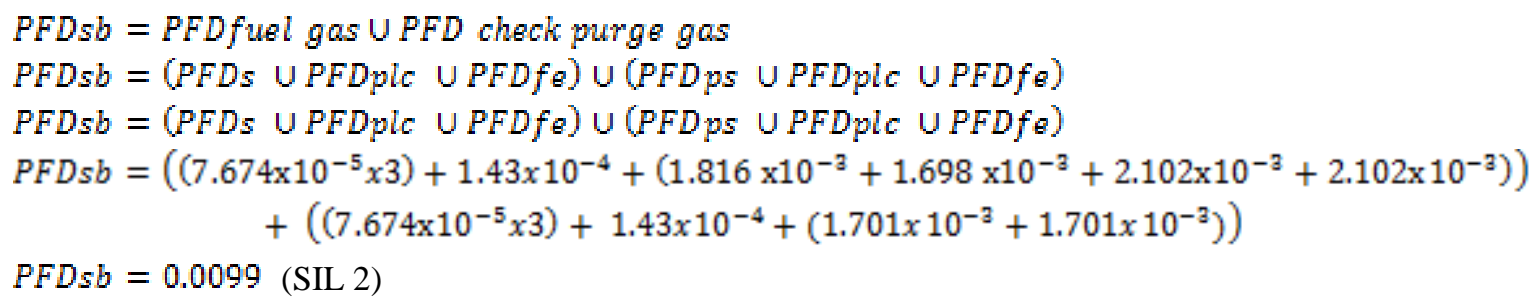




\section{CONCLUSION}

Based on research that has been done, it concluded as follows; Components PT-1018 and TT-1005 have a risk ranking of 20 were classified as high risk categories. While component of PT-1013, TT-1020 is included in moderate category, so it is necessary to reduce these risks by redesigning SIS for improve the SIL system. Superheat burner existing value SIL system for one with the PFD of the components of the final element ESDV having a value PFD greater than other component and Improved SIL system superheat burner reached SIL 2 with PFD 0.0099 by adding 2 pieces ESDV install series on each line feed fuel check gas and purge gas as well as the addition of a pressure switch again in any function switch (PSHH, PSL, PSLL).

\section{ACKNOWLEDGEMENT}

The authors would like to thank the Institute for Research and Community Service (LPPM ITS), Institut Technologi Sepuluh Nopember, Surabaya. With supporting financing the research. Also, the authors would like to thank the anonymous referees for their comments on the eelier version of this work.

\section{REFERENCES}

[1] A. PT. Petrokimia Gresik. Ammonia Plan I.

[2] Abouelrish, Ahmed. September 2015. Design of Boiler Burner Management System International Education \& Research Journal Volume-1 Issue-2

[3] Fault Tree Handbook with Aerospace Applications Version 1.1, NASA Publication, August

[4] ANSI/ISA-TR84.02. 2002. Safety Instrumented Functions (SIF) -Safety Integrity Level (SIL) Evaluation Techniques Part 1: Introduction. Research Triangle Park, NC: American National Standard Institute.

[5] ANSI/ISA-TR84.00.02-2002 Part 3. Safety Instrumented Function (SIF) - Safety Integrity Level (SIL) Evaluation Techniques Part 3: Determining the SIL of a SIF via Fault Tree Analysis. American National Standard Institute.

[6] Going Bill, 2000. Advanced Control Steam Superheat Temperature on a Utility Boiler. IEEE Research Journal Volume-3 Issue-2.

[7] IEC- 61882. 2001. Hazard and Operability Studies (Hasp Studies) - Application Guide. Geneva: International Electro technical Commission.

[8] John N. Dyer, Anya P. Raibagkar, Massimiliano Kolbe, and Ernesto Solano "Blast Damage Considerations for Horizontal Pressure Vessel and Potential for Domino Effects", the Italian Association of Chemical Engineering, Italy, 2012.

[9] Montgomery, Douglas C "Introduction to statistical Quality Control $6^{\text {th }}$ Edition”, United States of America. 2009.

[10] M. Marshal, Edward and W. Scarp, Eric, "Safety Integrity Level Selection.” (United State of America: Research Triangle Park, NC: ISA., 2002.

[11] Musyafa, A. And Kristianingsih, L., "Risk Management and Safety System Assessment from Power Plant Steam Boiler in Power Systems Unit 5, Paiton Indonesia", Australian Journal of Basic and Applied Sciences, 7(11) Sep 2013, Pages: 349-356, 2013.

[12] Musyafa, A. And Zulfiana, Erna., "Risk Management and Hazard and Operability Study on Steam Turbine Power Plant Unit 5 in The Power Generation Paiton, East Java-Indonesia”, Advances in Natural and Applied Sciences, 7(5) December 2013, Pages: 510-518, 2013.

[13] Mustafa, A. ,at.al., “ Hazad And Operability Study and Analysis of Safety Integrity Level Case Study: Ammonia Refrigerant Compressor at Petrochemical Plant" Advances in Natural and Applied Sciences, 9(8) July 2015, Pages: 36-42, AENSI Journals, 2015.

[14] Mustafa, A., at.al. "Reliability and Maintainability Assessment of the Steam Turbine Instrumentation System for optimization Operational Availability System at Fertilizer Plant", Australian Journal of Basic and Applied Sciences, 8(13) August 2014, Pages: 132-139, 2014.

[15]. Mustafa, A. et.al. "Evaluation of the Reliability and Prediction Maintenance on the Air Compressor System in Ammonia Plant PT. Petrokimia Gresik", Australian Journal of Basic and Applied Sciences, 9(11) May 2015, Pages: 853-862, 2015.

[16] Oakland, Josh S. 2003. Statistical Process Control $5^{\text {th }}$ edition. Butterworth Heinemann, Oxford.

[17] Poulose, Smear Maria, and Madhu, G., "Hazop Study for Process Plants: A Generalized Approach", International Journal of Emerging Technology and Advanced Engineering, 2012

[18] Rashid Quiche. Ali A.J Adam.” Reliability of Risk Assessment in petrochemical industries. International Journal of Industrial Management (IJM)". ISSN (Print) 22899286e-ISSN xxxx. Volume xx. Pp pp xx-xxJune, 2015. Universities Malaysia Pahang, Malaysia, 2015.

[19] Robert W. Johnson. "Beyond-compliance uses of HAZOP/LOPA studies”. Science Direct. Pp. 727-733., 2010. 
[20] Ronny D. Noriyati, et.al..." Reliability Assessment of Cooling Pump For Parts Inventory Planning in Power Plant System, Paiton-Indonesia”. Australian Journal of Basic and Applied Sciences, 8(13) August 2014, Pages: 140-146 AENSI ISSN: 1991-8178. Journal home page: www.ajbasweb.com, 2014.

[21] Ronny Dwi Noriyati, et.al. "Risk Assessment and Safety Analysis on Power Generation Boiler at PT.Petrokimia Gresik,Indonesia”. The 2015 International Applied Reliability Symposium, Asia Pacific, October 7 - 9, 2015 Singapore

[22] Ronny Dwi Noriyati, et.al . "Hazard \& operability study and determining safety integrity level on sulfur furnace unit: A case study in fertilizer industry". Available online at www.sciencedirect.com. Procedia Manufacturing 4 ( 2015 ) 231 - 236.

[23] Ronny D. Noriyati, et.al. "Hazard and Operability Study and Risk Management Case Study: Phosphoric Acid Concentration Process in Petrochemical Plant - Indonesia". International Journal of Engineering \& Technology IJET-IJENS Vol:16 No:01. 164401-3838-IJET-IJENS @ February 2016 IJENS

[24] Silvana D. Costa. et. al. "Evaluation Safety Integrity Level Using Layer of Protection Analysis in Recycle Gas First Stage Cycle Compressor at PT. Pertamina Persero" ., Australian Journal of Basic and Applied Sciences, 9(20) June 2015, Pages: 154-163, 2015.

[25] Skrtic, Lana, "Hydrogen Sulfide, Oil and Gas, and People's Health", Energy and Resources Group University of California, Berkeley. 2006.

[26]. summers, Angela. "Safety Integrity Level: Do You Understand The Odds?" (Journal of Control Engineering, SISTECH solution, LLC, 2000.

[27]. Temilade Ladokun, Farhad , “Accidents in Pressure Vessels: Hazard Awareness", World Congress on Engineering, U.K. ,2010.

[28]. The Norwegian oil industry association, OLF Recommended Guidelines for the application of IEC 61508 and IEC 61511 in the petroleum activities on the Norwegian Continental Shelf, No.: 070 Date effective: 1.0 2, .2001.

ANNEX-1.

HAZOP Node superheat burner

\begin{tabular}{|c|c|c|c|c|c|c|c|c|c|c|c|}
\hline $\mathrm{NO}$ & $\begin{array}{l}\text { Compon } \\
\text { ent }\end{array}$ & Description & $\begin{array}{l}\text { Guide } \\
\text { word }\end{array}$ & $\begin{array}{l}\text { Deviat } \\
\text { ion }\end{array}$ & Cause & $\begin{array}{l}\text { Conseque } \\
\text { nces }\end{array}$ & Safeguard & $\mathrm{L}$ & $\mathrm{C}$ & RR & $\begin{array}{l}\text { Recommend } \\
\text { ation }\end{array}$ \\
\hline \multirow[t]{2}{*}{1} & \multirow[t]{2}{*}{ TT1005 } & \multirow[t]{2}{*}{$\begin{array}{l}\text { Temperature } \\
\text { Transmitter }\end{array}$} & High & $\begin{array}{l}\text { High } \\
\text { Temp } \\
\text { eratur } \\
\text { e }\end{array}$ & $\begin{array}{l}\text { More } \\
\text { flow of } \\
\text { feed fuel } \\
\text { gas on } \\
\text { superheat } \\
\text { burner }\end{array}$ & $\begin{array}{l}\text { Overpress } \\
\text { ure, } \\
\text { potentially } \\
\text { cause } \\
\text { leaking on } \\
\text { tube and } \\
\text { blown in } \\
\text { burner }\end{array}$ & $\begin{array}{l}\text { Control valve } \\
\text { TV1005 } \\
\text { High pressure } \\
\text { alarm } \\
\text { PAH1141 } \\
\text { Interlock } \\
\text { 101BBS with } \\
\text { PSHH1241 } \\
\text { actuating } \\
\text { Control } \\
\text { Valve } \\
\text { XV1241A \& } \\
\text { XV1241B }\end{array}$ & 4 & 5 & $\mathrm{H} 20$ & $\begin{array}{l}\text { Calibrate for } \\
\text { time period } \\
\text { Preventive } \\
\text { maintenance } \\
\text { Redesign } \\
\text { SIS burner }\end{array}$ \\
\hline & & & Low & $\begin{array}{l}\text { Low } \\
\text { Temp } \\
\text { eratur } \\
\text { e }\end{array}$ & $\begin{array}{l}\text { Less } \\
\text { flow of } \\
\text { feed fuel } \\
\text { gas on } \\
\text { superheat } \\
\text { burner }\end{array}$ & $\begin{array}{l}\text { Bad steam } \\
\text { quality, } \\
\text { steam } \\
\text { cannot } \\
\text { reach the } \\
\text { design } \\
\text { temperatu } \\
\text { re }\end{array}$ & $\begin{array}{l}\text { Control valve } \\
\text { TV1005 } \\
\text { Low Pressure } \\
\text { alarm } \\
\text { PAL1140 } \\
\text { Interlock } \\
\text { 101BBS with } \\
\text { PSLL1241 } \\
\text { actuating } \\
\text { Control } \\
\text { Valve } \\
\text { XV1241A \& } \\
\text { XV1241B }\end{array}$ & 4 & 5 & $\mathrm{H} 20$ & $\begin{array}{l}\text { Preventive } \\
\text { maintenance } \\
\text { Calibrate for } \\
\text { time period } \\
\text { Redesign } \\
\text { SIS burner }\end{array}$ \\
\hline 2 & PT1018 & $\begin{array}{l}\text { Pressure } \\
\text { Transmitter }\end{array}$ & High & $\begin{array}{l}\text { High } \\
\text { Pressu } \\
\text { re }\end{array}$ & $\begin{array}{l}\text { Burning } \\
\text { temperat } \\
\text { ure in } \\
\text { superheat } \\
\text { ed too }\end{array}$ & $\begin{array}{l}\text { Overpress } \\
\text { ure Cause } \\
\text { leaking or } \\
\text { mechanica } \\
1 \text { damaged }\end{array}$ & $\begin{array}{l}\text { Control valve } \\
\text { PV1018A \& } \\
\text { PV1018B } \\
\text { failsafe in fail } \\
\text { open state }\end{array}$ & 4 & 5 & H20 & $\begin{array}{l}\text { Prenventive } \\
\text { maintance } \\
\text { Overhaul } \\
\text { every turn } \\
\text { around }\end{array}$ \\
\hline
\end{tabular}




\begin{tabular}{|c|c|c|c|c|c|c|c|c|c|c|c|}
\hline $\mathrm{NO}$ & $\begin{array}{l}\text { Compon } \\
\text { ent }\end{array}$ & Description & $\begin{array}{l}\text { Guide } \\
\text { word }\end{array}$ & $\begin{array}{l}\text { Deviat } \\
\text { ion }\end{array}$ & Cause & $\begin{array}{l}\text { Conseque } \\
\text { nces }\end{array}$ & Safeguard & $\mathrm{L}$ & $\mathrm{C}$ & RR & $\begin{array}{l}\text { Recommend } \\
\text { ation }\end{array}$ \\
\hline & & & & & high & $\begin{array}{l}\text { for steam } \\
\text { pipe, 101- } \\
\text { C, 102-C }\end{array}$ & & & & & \\
\hline & & & Low & $\begin{array}{l}\text { Low } \\
\text { Pressu } \\
\text { re }\end{array}$ & $\begin{array}{l}\text { Less } \\
\text { steam } \\
\text { flow \& } \\
\text { Burning } \\
\text { temperat } \\
\text { ure in } \\
\text { superheat } \\
\text { ed too } \\
\text { low }\end{array}$ & $\begin{array}{l}\text { Poor } \\
\text { steam } \\
\text { quality }\end{array}$ & $\begin{array}{l}\text { Control valve } \\
\text { PV1018A \& } \\
\text { PV1018B } \\
\text { failsafe in fail } \\
\text { open state }\end{array}$ & 4 & 5 & $\mathrm{H} 20$ & $\begin{array}{l}\text { Prenventive } \\
\text { maintance } \\
\text { Overhaull } \\
\text { every turn } \\
\text { around }\end{array}$ \\
\hline \multirow[t]{2}{*}{3} & \multirow[t]{2}{*}{ PT1013 } & \multirow[t]{2}{*}{$\begin{array}{l}\text { Pressure } \\
\text { Transmitter }\end{array}$} & High & $\begin{array}{l}\text { High } \\
\text { Pressu } \\
\text { re }\end{array}$ & $\begin{array}{l}\text { Burning } \\
\text { temperat } \\
\text { ure in } \\
\text { superheat } \\
\text { ed too } \\
\text { high } \\
\end{array}$ & $\begin{array}{l}\text { Overpress } \\
\text { ure cause } \\
\text { mechanica } \\
1 \text { damaged } \\
\text { for steam } \\
\text { pipe line } \\
\end{array}$ & $\begin{array}{l}\text { PAH alarm } \\
\text { high indicator } \\
\text { Control valve } \\
\text { PV1013 } \\
\text { failsafe in fail } \\
\text { close state }\end{array}$ & 3 & 2 & M6 & $\begin{array}{l}\text { Calibrate for } \\
\text { time period }\end{array}$ \\
\hline & & & Low & $\begin{array}{l}\text { Low } \\
\text { Pressu } \\
\text { re }\end{array}$ & $\begin{array}{l}\text { Less } \\
\text { steam } \\
\text { product } \\
\text { from } \\
\text { Primary } \\
\text { Reformer } \\
101-B\end{array}$ & $\begin{array}{l}\text { Less } \\
\text { steam } \\
\text { distributed } \\
\text { to } \\
\text { ammonia } \\
\text { system } \\
\text { unbalance }\end{array}$ & $\begin{array}{l}\text { Control valve } \\
\text { PV1013 } \\
\text { failsafe in fail } \\
\text { close state }\end{array}$ & 3 & 2 & M6 & $\begin{array}{l}\text { Give alarms } \\
\text { system for } \\
\text { indicating an } \\
\text { PAL }\end{array}$ \\
\hline \multirow[t]{2}{*}{4} & \multirow[t]{2}{*}{ TT1020 } & \multirow[t]{2}{*}{$\begin{array}{l}\text { Temperature } \\
\text { Transmitter }\end{array}$} & High & $\begin{array}{l}\text { High } \\
\text { Temp } \\
\text { eratur } \\
\text { e }\end{array}$ & $\begin{array}{l}\text { Less } \\
\text { water } \\
\text { flow } \\
\text { from } \\
104 \mathrm{~J} / \mathrm{JA} \\
\text { into de } \\
\text { superheat } \\
\text { er }\end{array}$ & $\begin{array}{l}\text { Pressure } \\
\text { increase }\end{array}$ & $\begin{array}{l}\text { TAH alarm } \\
\text { high indicator } \\
\text { Control valve } \\
\text { PV1020 } \\
\text { failsafe in fail } \\
\text { close state }\end{array}$ & 2 & 3 & M6 & $\begin{array}{l}\text { Calibrate \& } \\
\text { preventive } \\
\text { maintenance } \\
\text { for time } \\
\text { period }\end{array}$ \\
\hline & & & Low & $\begin{array}{l}\text { Low } \\
\text { Temp } \\
\text { eratur } \\
\text { e }\end{array}$ & $\begin{array}{l}\text { More } \\
\text { water } \\
\text { flow } \\
\text { from } \\
104 \mathrm{~J} / \mathrm{JA} \\
\text { into de } \\
\text { superheat } \\
\text { er }\end{array}$ & $\begin{array}{l}\text { Bad steam } \\
\text { quality for } \\
\text { medium } \\
\text { steam } \\
\text { distributio } \\
\mathrm{n}\end{array}$ & $\begin{array}{l}\text { Control valve } \\
\text { PV1020 } \\
\text { failsafe in fail } \\
\text { close state }\end{array}$ & 2 & 3 & M6 & $\begin{array}{l}\text { Give alarms } \\
\text { TAL for } \\
\text { indicating } \\
\text { Calibrate \& } \\
\text { preventive } \\
\text { maintenance }\end{array}$ \\
\hline 5 & FI1031 & $\begin{array}{l}\text { Flow } \\
\text { Transmitter }\end{array}$ & More & $\begin{array}{l}\text { More } \\
\text { Flow }\end{array}$ & $\begin{array}{l}\text { More } \\
\text { flow } \\
\text { from gas } \\
\text { service }\end{array}$ & $\begin{array}{l}\text { Pipe } \\
\text { overpress } \\
\text { ure May } \\
\text { be cause a } \\
\text { pre- } \\
\text { ignition } \\
\text { on pipe } \\
\text { Superheat } \\
\text { burner } \\
\text { overheat, } \\
\text { potentially } \\
\text { explosion } \\
\text { on } \\
\text { superheat }\end{array}$ & $\begin{array}{l}\text { PSHH 1241, } \\
\text { PSH 1141, } \\
\text { and PAH } \\
\text { Safety system } \\
\text { actuating } \\
\text { interlock I } \\
\text { 101BBS to } \\
\text { cut off gas } \\
\text { flow }\end{array}$ & 2 & 3 & M6 & $\begin{array}{l}\text { Calibrate \& } \\
\text { preventive } \\
\text { maintenance } \\
\text { for time } \\
\text { period }\end{array}$ \\
\hline
\end{tabular}




\begin{tabular}{|c|c|c|c|c|c|c|c|c|c|c|c|}
\hline $\mathrm{NO}$ & $\begin{array}{l}\text { Compon } \\
\text { ent }\end{array}$ & Description & $\begin{array}{l}\text { Guide } \\
\text { word }\end{array}$ & $\begin{array}{l}\text { Deviat } \\
\text { ion }\end{array}$ & Cause & $\begin{array}{l}\text { Conseque } \\
\text { nces }\end{array}$ & Safeguard & $\mathrm{L}$ & $\mathrm{C}$ & RR & $\begin{array}{l}\text { Recommend } \\
\text { ation }\end{array}$ \\
\hline & & & & & & burner & & & & & \\
\hline & & & Less & $\begin{array}{l}\text { Less } \\
\text { Flow }\end{array}$ & $\begin{array}{l}\text { Lacking } \\
\text { on gas } \\
\text { pipe }\end{array}$ & $\begin{array}{l}\text { Superheat } \\
\text { burner } \\
\text { cannot } \\
\text { reach } \\
\text { design } \\
\text { temperatu } \\
\text { re, poor } \\
\text { steam } \\
\text { quality }\end{array}$ & $\begin{array}{l}\text { PSL1142. } \\
\text { PSL1140, } \\
\text { Alarm on } \\
\text { DCS PAL } \\
1140, \\
\text { Safety system } \\
\text { actuating } \\
\text { interlock I } \\
\text { 101BBS to } \\
\text { cut off gas } \\
\text { flow }\end{array}$ & 2 & 3 & M6 & $\begin{array}{l}\text { Calibrate \& } \\
\text { preventive } \\
\text { maintenance } \\
\text { for time } \\
\text { period }\end{array}$ \\
\hline \multirow[t]{2}{*}{6} & \multirow[t]{2}{*}{ TI1336 } & \multirow[t]{2}{*}{$\begin{array}{l}\text { Temperature } \\
\text { Transmitter }\end{array}$} & High & $\begin{array}{l}\text { High } \\
\text { Temp } \\
\text { eratur } \\
\text { e }\end{array}$ & $\begin{array}{l}\text { Flow } \\
\text { process } \\
\text { gas too } \\
\text { high }\end{array}$ & $\begin{array}{l}\text { Steam } \\
\text { temperatu } \\
\text { re inlet } \\
\text { superheat } \\
\text { burner too } \\
\text { high }\end{array}$ & $\begin{array}{l}\text { Loop } \\
\text { temperature } \\
\text { control TT- } \\
1005\end{array}$ & 1 & 2 & L2 & $\begin{array}{l}\text { Check and } \\
\text { scheduling } \\
\text { service }\end{array}$ \\
\hline & & & Low & $\begin{array}{l}\text { Low } \\
\text { Temp } \\
\text { eratur } \\
\text { e }\end{array}$ & $\begin{array}{l}\text { Low } \\
\text { flow of } \\
\text { process } \\
\text { gas }\end{array}$ & $\begin{array}{l}\text { Cannot } \\
\text { reach } \\
\text { steam } \\
\text { temperatu } \\
\text { re design. }\end{array}$ & $\begin{array}{l}\text { Loop } \\
\text { temperature } \\
\text { control TT- } \\
1006\end{array}$ & 1 & 2 & $\mathrm{~L} 2$ & $\begin{array}{l}\text { Check and } \\
\text { scheduling } \\
\text { service }\end{array}$ \\
\hline 7 & TV-1005 & Control Valve & Open & $\begin{array}{l}\text { Fail to } \\
\text { open }\end{array}$ & $\begin{array}{l}\text { System } \\
\text { control } \\
\text { fail } \\
\text { no signal } \\
\text { control }\end{array}$ & $\begin{array}{l}\text { No gas } \\
\text { flow into } \\
\text { burner }\end{array}$ & $\begin{array}{l}\text { Line by pass } \\
\text { Pressure } \\
\text { regulator } \\
\text { valve }\end{array}$ & 1 & 3 & L3 & $\begin{array}{l}\text { Check and } \\
\text { scheduling } \\
\text { service }\end{array}$ \\
\hline 8 & PV-1018 & Control Valve & Close & $\begin{array}{l}\text { Fail to } \\
\text { close }\end{array}$ & $\begin{array}{l}\text { System } \\
\text { control } \\
\text { fail } \\
\text { no signal } \\
\text { control }\end{array}$ & $\begin{array}{l}\text { Flow } \\
\text { process } \\
\text { gas too } \\
\text { high } \\
\text { steam } \\
\text { temperatu } \\
\text { re from } \\
102 C \text {, } \\
\text { overpress } \\
\text { ure steam } \\
\text { inlet } \\
\text { primary } \\
\text { reformer }\end{array}$ & $\begin{array}{l}\text { Line by pass } \\
\text { hand valve } \\
\text { manually } \\
\text { operated }\end{array}$ & 1 & 3 & L3 & $\begin{array}{l}\text { Check and } \\
\text { scheduling } \\
\text { service }\end{array}$ \\
\hline 9 & PV-1013 & Control Valve & Open & $\begin{array}{l}\text { Fail to } \\
\text { open }\end{array}$ & $\begin{array}{l}\text { System } \\
\text { control } \\
\text { fail } \\
\text { no signal } \\
\text { control }\end{array}$ & $\begin{array}{l}\text { Cannot } \\
\text { distribute } \\
\text { MP steam }\end{array}$ & $\begin{array}{l}\text { Line by pass } \\
\text { with hand } \\
\text { valve } \\
\text { manually } \\
\text { operated }\end{array}$ & 1 & 2 & L2 & $\begin{array}{l}\text { Check and } \\
\text { scheduling } \\
\text { service }\end{array}$ \\
\hline 10 & TV-1020 & Control Valve & Open & $\begin{array}{l}\text { Fail to } \\
\text { open }\end{array}$ & $\begin{array}{l}\text { System } \\
\text { control } \\
\text { fail } \\
\text { no signal } \\
\text { control }\end{array}$ & $\begin{array}{l}\text { Steam } \\
\text { quality for } \\
\text { MP } \\
\text { distributio } \\
\mathrm{n} \\
\text { decreasing }\end{array}$ & $\begin{array}{l}\text { Line by pass } \\
\text { valve } \\
\text { manually } \\
\text { hand operated }\end{array}$ & 1 & 2 & L2 & $\begin{array}{l}\text { Check and } \\
\text { scheduling } \\
\text { service }\end{array}$ \\
\hline
\end{tabular}

